\title{
Biotechnologizing Jatropha for local sustainable development
}

\author{
Daniel Puente-Rodríguez
}

Accepted: 18 March 2009/Published online: 22 August 2009

(c) The Author(s) 2009. This article is published with open access at Springerlink.com

\begin{abstract}
This article explores whether and how the biotechnologization process that the fuel-plant Jatropha curcas is undergoing might strengthen local sustainable development. It focuses on the ongoing efforts of the multi-stakeholder network Gota Verde to harness Jatropha within local small-scale production systems in Yoro, Honduras. It also looks at the genomics research on Jatropha conducted by the Dutch research institute Plant Research International, specifically addressing the ways in which that research can assists local development in Honduras. A territorial approach is applied for analysis employing a three domain concept (local sustainable biotechnological development) of territory, technology and re-territorialization. The article suggests that, although the biotechnologization process (through genomics) of Jatropha within the socio-technical framework of the institute and multi-stakeholder networks is an ongoing process-and different trajectories are, therefore, still open-the process can, nevertheless, strengthen local sustainable development.
\end{abstract}

\section{Keywords}

Local sustainable biotechnological developments .

Genomics · Biofuels · Jatropha curcas · Gota Verde ·

Honduras · PRI-WUR · Territorialization

\author{
Abbreviations \\ BP British Petroleum \\ BYSA Biocombustibles de Yoro Sociedad Anónima
}

D. Puente-Rodríguez $(\bowtie)$

Social Sciences Group, Wageningen University, Hollandseweg

1, $6706 \mathrm{KN}$ Wageningen, The Netherlands

e-mail: Daniel.Puente@wur.nl
CEVER Centro de Educación Vocacional Evangélico y Reformado "Dr. Ned van Steenwijk"

FHIA Fundación Hondureña de Investigación Agrícola

FUNDER Fundación para el Desarrollo Empresarial Rural

MDPL Movimiento por el Desarme hacia la Paz y la Libertad

NGO Non governmental organization

PPO Pure plant oil

PRI Plant Research International

STRO Social Trade Organization

WUR Wageningen University and Research Centre

\section{Introduction}

Jatropha curcas is emerging within academic, civil society, and policy circles as an interesting crop for strengthening the agrarian systems of resource-poor farmers. Jatropha has not traditionally been used as a crop, however, and a scientification and biotechnologization ${ }^{1}$ process has therefore been initiated aimed at increasing efficiency in its cultivation. The scientification and biotechnologization processes are conducted in part through genomics. Genomics technologies have mainly been developed in high-tech labs in the industrially developed parts of the Northern Hemisphere, so developing trajectories aimed at orienting the

\footnotetext{
${ }^{1}$ In this paper, "biotechnology" is understood as "any technological application that uses biological systems, living products, or processes for specific purposes" (Adler 2000, p. 175). Herein, biotechnology refers to a large set of technologies ranging from fermentation processes to the latest applications of genomics.
} 
biotechnologization of Jatropha towards local sustainable developments within peasant agrarian systems emerges as a difficult task. This article takes up the challenge to explore whether and how the biotechnologization process, through genomics, that the fuel-plant Jatropha curcas is currently undergoing, might in fact strengthen local sustainable developments.

In order to address this central question, I examined the interaction between two networks. The first one is organized around a project conducted by the Dutch research institute Plant Research International (PRI) ${ }^{2}$ at Wageningen University and Research Centre (WUR), which is applying genomic technologies to analyze the global diversity of Jatropha. The project's objectives are to map this diversity and develop trait-related molecular markers, and in this way establish the basis for future plant breeding projects (i.e. the biotechnologization of Jatropha). This project aims to improve the performance of Jatropha for large-scale as well as for small-scale systems. The article also explores a local multi-stakeholder network (Gota Verde $^{3}$ ) comprised of peasants, NGOs, and research institutes involved with growing, transforming and using Jatropha and its products by and for the benefit of peasants in the Department of Yoro, Honduras.

This study was conducted over a period of 8 months (December, 2007-July, 2008). Data were collected through a combination of literature review, key informant interviews and discussions, and personal observation. The relevant literature included a variety of internal documents from the PRI project and Gota Verde network (proposals, reports, contracts, etc.). Over sixty, semi-structured interviews were conducted with PRI researchers, Gota Verde stakeholders, NGO practitioners, Jatropha producers and other relevant stakeholders in Honduras and in the Netherlands. Six discussion groups were organized. The additional personal observations were made in the Jatropha fields or in institutions, through meetings within or between organizations.

This article starts by defining the concept of local sustainable biotechnological developments. Essentially this concept focuses on the mutual interactions between the social and material elements of biotechnologies, and the relation of those interactions with global trends in biotechnological developments. It has three interrelated analytic domains: (1) the territorial, (2) the technological, and that of (3) re-territorialization. The third section explores the territorial approach of the multi-stakeholder network Gota Verde to the development of local sustainable Jatropha production and utilization systems. Next, the technological aspects of the Jatropha genomics research conducted by PRI are examined. Whether and how the

\footnotetext{
2 www.jatropha.wur.nl.

${ }^{3}$ Green drop: www.gotaverde.org.
}

biotechnologization process (through genomics) that Jatropha is undergoing might strengthen the local developments in Yoro is discussed in "The domain of re-territorialization: local and global interaction". The conclusion stresses that, although the biotechnologization process within the socio-technological framework of these multistakeholder networks is an ongoing process-and that, therefore, different and even contradictory trajectories are still open-it can nevertheless strengthen the local sustainable developments in Yoro.

\section{Local sustainable biotechnological developments: a territorial approach to developing genomics}

Genomic technologies are acknowledged as a valuable means for addressing certain agrarian problems of the peasantry (Delmer 2005; Bruskiewich et al. 2006; Louwaars et al. 2006). The initial information produced by genomics about the entire genome of organisms through sequencing form the basis for functional genomics and its search for a further understanding of gene expression and biological activity (e.g., plant processes as growth, resistance to biotic and abiotic stresses, etc.). This knowledge might become functional through molecular technologies; for example, by assisting plant breeding programs. However, genomics has been developed within societies with large technological capacities. Therefore, the abstract de-territorialized assumption that certain genomics technologies developed within specific socio-technological conditions could be deployed for the strengthening of resource-poor farming agrarian systems emerges as a questionable idea.

This type of de-territorialized and abstract approach to the development of biotechnologies usually fails to reach resource-poor farmers for two main reasons. Firstly, it is unsuccessful because of its assumed conception of territories as abstract functional locations without social or environmental specificities. Secondly, it fails because of its understanding of biotechnologies as essentially material entities without social dimensions. The "territorial approach" to the advance of biotechnologies, on the other hand, is captured by the concept of "local sustainable biotechnological developments." This alternative approach understands territories as socially constructed places developed by the mutual interaction between (and within) social groups and natural environments (Hettne 1995, Magnaghi 2005). Moreover, it understands technologies as political entities (Winner 1985), or socio-technological systems (Sclove 1995, Puente-Rodríguez 2008; Feenberg 1999). Within this approach, the way in which technologies are designed, developed and deployed is directly related to the actors involved in these processes and the choices they 
make. Here, however, we admit also the material specificities added by technologies themselves to socio-technological systems, and focus, therefore, on the mutual shaping process that occurs between the social and material elements of biotechnologies. Thus, rather than developing genomics applications in chic Northern or urban labs to be sent later to peasant communities, this article argues that the territorialization of biotechnologies is necessary within (and with the consent of) the rural communities they are supposed to serve.

It is argued here that a territorial approach to biotechnology development should consider, at least three interrelated analytic domains, namely: (1) The territorial domain, (2) The technological domain, and (3) The domain of reterritorialization.

\section{The territorial domain}

The territorial domain concerns the human (power) relations (networks) within a given territory effective for the development of a certain technology. It emerges in reaction to the abstract understanding in which biotechnologies are developed and presumes that the technology's potential applicability exists regardless the particulars of the locality. In the abstract context, actors are anonymous individuals organized in hierarchical networks (Hettne 1995). Against this, territorial practice consists of a geographically-bounded community that self-manages a particular set of natural and human resources. In this context, a biotechnological system aimed at strengthening the agrarian territories of peasants should consider the peculiarities and needs of these territories (e.g., local crop and livestock varieties, pests, rainfall patterns, and local agrarian practices and knowledge). In reality, biotechnologies have mainly focused on crops which are relevant for global markets (Fears 2007), while many crops that are neglected at the global level are crucial for peasants at the local level for food production (e.g., Andean tubers and roots) or for other purposes such as healthcare or providing fuel (e.g., Jatropha curcas).

Making this direct relationship between (bio)technology development and a specific territory is an act of "territorializing technologies." Territorializing biotechnologies-within the conceptual framework presentedalso involves a political dimension, an extension of social participation in decision making-or in other words, inclusion of the excluded-both with respect to the management of local resources and to the development of the (bio)technologies in question. For this article, the territorial domain encompasses the strategies of local multi-stakeholder networks aimed at creating sustainable systems to produce and utilize Jatropha in the department of Yoro, Honduras.
The technological domain

The technological domain concerns the analysis of the material elements of a biotechnological development. Actually, of course, the material level is interrelated with the social, the two are co-constructing each other within technological systems (and considered here separately only for analytical reasons). Ruivenkamp et al. (2008, p. 16) elaborate further on this material and social co-creation of technologies through the concept reconstruction of technologies. They argue that:

It takes as axiomatic the view that specific values are excluded from original design (Feenberg 1999); that technology has a specific code which is socially structured and biased, reflecting the unequal distribution of power (Noble 1978); that technology has politics (Winner 1985); and that social/technoactivists networks are able to change the values, codes and politics of technology.

The act of reconstruction is a deliberate act of re-creation, applied at the level of knowledge systems and technical artifacts: "it takes place by changing the social relations from which the artifacts emerge, as well as by modifying the material content of the artifact" (ibid.). Not only is a social action required in order to achieve local sustainable development of biotechnologies, as described by the territorial domain, but also a material reconstruction of the apparatuses themselves. The analysis implied by a technological domain also reflects a belief that other alternative (bio)technological developments are, in fact, feasible.

In this article, the technological domain addresses the biotechnologization process that Jatropha is undergoing within the globally oriented project conducted by PRI in the Netherlands. It explores the tensions released by this biotechnologization process which is strengthening the developmental capacities of the local production systems of Jatropha in Yoro, Honduras.

\section{The domain of reterritorialization}

The relationship between the social and the natural elements of a territory is largely mediated by technology usage. During the territorializing process of biotechnologies, therefore, a re-territorialization occurs that reflects the social and material strategies and changes of the process.

Biotechnologies have acquired new codes (e.g., inclusion of peasant needs) which requires that they be adapted to the societies of a given territory. Societies have to adapt also to the new technologies. Therefore, new partnerships and identities appear or old partnerships and identities are transformed-for example, NGOs can become producers of biotechnologies (Puente-Rodríguez 2007). Moreover, global 
and local relationships are reconstructed. Global forces within the biotechnological developments collaborate with, rather than merely assimilate, local networks. In this context, historical processes that the biotechnologization of agriculture bring about-such as appropriation (Goodman et al. 1987), or scientification (van der Ploeg 1987) are challenged.

The concept of local sustainable biotechnological developments is a normative one, holding that through the introduction of values such as justice or democracy into the process of biotechnology development, the new technologies can become a vehicle for local sustainable development. In this article the domain of re-territorialization works as a reflective moment in regard to both about how the biotechnologization of Jatropha might strengthen the small-scale production systems of Yoro, and of the meaning of these dynamics within the global and historical trends of biotechnological development.

To conclude, local sustainable biotechnological developments are defined as those types of development that strengthen the peasant agrarian systems of a territory, based on the re-construction of biotechnologies mainly (though not exclusively) by and for the locality. The case of Jatropha presented in this article is to a certain extent an illustration of these types of developments.

\section{The territorial domain: Harnessing Jatropha within local sustainable production systems in Yoro, Honduras}

Honduras is a poor country. Most of the country's poor live in rural areas and depend on agriculture to survive. Poverty in these areas continues to increase (Jansen et al. 2006). In the rural department of Yoro, the average income is US\$ 1.8 a day, the malnutrition rate $33 \%$, and only $10 \%$ of the population have sewage systems (MAMUNCRAC 2007). Honduras is sometimes seen as the prototype of a banana republic. The main crops cultivated in the local, low-input agriculture are maize and beans used for household consumption, but over half of the arable land is owned by either the government or the two largest banana companies (Humphrey 1997), while the huge majority (72\%) of agricultural producers own very little $(11.6 \%)$ of the cultivated area, and $35.8 \%$ of rural families are landless (Gottret 2007).

Developmental efforts in Honduras are vulnerable to, among other things, natural adversities, shifting international agrarian power relations, and fluctuations in the price of oil. The country depends heavily on external petroleum (Rothkopf 2007). It was in this context that the President of Honduras, Manuel Zelaya, announced in April 2006 that the domestic energy consumption would be based primarily on biodiesel within five years (La Prensa 2006), and the Bio-fuels Production and Consumption Law for the promotion of bio-fuels was introduced.
The majority of biodiesel produced in Honduras comes from palm oil. The production of palm oil is in the hands of two large private companies (Rothkopf 2007). Honduras ranks sixth in the world in terms of area of palm oil cultivated and the production of palm oil has more than doubled over the last decade. However, more than the half of this palm oil was not used to cover local energy needs, but it was exported (ibid.).

\section{Territory, energy and Jatropha}

The shrub Jatropha curcas belongs to the Euphorbeaceae family. Due to the toxicity of its leaves, the Jatropha is extensively used for hedging to protect arable land and orchards form cattle (as "living fences"). In Yoro, it has also been a garden tree, with its seeds used to produce soap and medicines. Although it is not uncommon to find women in rural communities of Yoro who know how to make soap or prepare a dosage for laxative purposes, the use of Jatropha does seem to have been decreasing in recent years, due to the introduction of industrial soap, pharmaceutical medicines, and other tree varieties for living fences. From field work in Yoro, it is clear that Jatropha oil is rarely extracted for use as fuel. Nevertheless, the plant might have significant potential for lighting and cooking purposes in this region, since few households have access to electricity (5\%) and the vast majority rely upon wood as their source of energy (86\%) (MAMUNCRAC 2007). The official figure for the area planted with Jatropha in Honduras (March 2008) is around $424 \mathrm{ha},{ }^{4}$ of which 350 ha is located in the southern department of Choluteca and owned by the corporation Agroipsa. There are two other small areas with a total of 13 ha. ${ }^{5}$ Gota Verde is responsible for planting the remaining 61 ha of Jatropha, of which 11 ha is set aside for research purposes.

\section{The Gota Verde network}

The multi-stakeholder network coordinated by the project Gota Verde is aimed at promoting the local production and utilization of biofuels, organized mainly around Jatropha. ${ }^{6}$ The project is financed by the European Community and

\footnotetext{
4 Victor Iscoa, Secretary of State for Agriculture and Livestock, 2008, "personal communication". This area does not include Jatropha living fences.

56 ha are owned by the Dinan Corporation in the department of Comayagua while the farmer Federico Mejías has 7 ha in San Esteban area in the department of Olancho.

${ }^{6}$ Gota Verde is currently producing around 7951 of biodiesel from used cooking oil from restaurants. Also, a scheme has been initiated-organized in coordination with the Spanish NGO Movimiento por la Paz hacia el Desarme y la Libertad (MPDL) and local schools-to involve local children in the recollection of domestic oil.
} 
two Dutch foundations, and coordinated by the Dutch NGO Social Trade Organization (STRO). ${ }^{7}$ It is organized around small to medium-scale farmers, with some 200 peasants and farmers currently linked to the network. The Gota Verde project is supporting the foundation of a company $\left(\mathrm{BYSA}^{8}\right)$ whose objective is to grow oleaginous crops (including castor, sunflower, soybean, and canola, but with Jatropha as core plant) for the production and distribution of biofuels, and their derivates (soap, bio-fertilizers, biogas, etc.). The Honduran non-profit private organization FUNDER $^{9}$ is supporting the foundation of the BYSA company taking a $51 \%$ stake in the company, which it will keep until BYSA is economically viable, when it will withdraw. Other than FUNDER, only Jatropha farmers are permitted to own BYSA shares. The farmers involved in the project have all been issued ten shares, representing the estimated value of their investment in Jatropha. ${ }^{10}$ To avoid a takeover of the company by an external investor, the BYSA general assembly has put a cap of 5\% on company share ownership by any one individual or company. FUNDER is monitoring BYSA's management and giving farmers agrarian support for growing Jatropha. It employs mainly local technicians for its agrarian activities.

The other main Honduran institute coordinated within the Gota Verde network is FHIA. ${ }^{11}$ FHIA works on the agronomic performance of Jatropha, for which purpose it cultivates $11 \mathrm{ha}$. Six imported varieties are planted in these fields. The project studies how these lines grow under different conditions with respect to pruning, irrigation, fertilization (related to soil characteristics), intercropping, and marginal soils. It has established nurseries to deliver seeds to peasants. FHIA is the organization that should play the major role in the translation of the genomic knowledge produced by PRI to the locality-or the reintegration back into the locality of knowledge extracted from local varieties of Jatropha by PRI in The

\footnotetext{
7 www.strohalm.nl.

${ }^{8}$ Biocombustibles de Yoro Sociedad Anónima.

9 (Fundación de Desarrollo Empresarial Rural) The main objective of FUNDER is to promote local development by supporting small to medium-scale farmers through (micro) credit, and by allocating startup funds for small-scale companies and cooperatives in rural Honduras. www.funder.hn.

10 The investment has been supported with credit from the project, in which farmers received seeds, inputs and some economic support for the management of the crop. Loans for the plants are to be issued interest-free for an indefinite period, and additional loans for inputs and land preparation will be accessible at below market interest rates. All loans are to be issued in kind and it is proposed to withhold $30 \%$ of the value of the seeds sold to BYSA, in order to repay the loans, with the remaining $70 \%$ to be paid in cash or (later on in the project) by BYSA product vouchers (see main text).

${ }^{11}$ Fundación Hondureña de Investigación Agrícola is a non-profit private research institute offering its expertise and services to (non-) governmental organizations and industry. www.fhia.org.hn.
}

Netherlands (discussed later). In theory FHIA has the knowledge and capacity to implement it; but the fact that it works primarily on the basis of contracts and does not have additional funds for its own research agenda might jeopardize this if no supplementary funding is found once the project is concluded.

The Dutch NGO STRO not only coordinates Gota Verde, but it is also responsible for the design and implementation of a complementary currency system. The intention is to create a preferential trade space at the local and regional levels. Within this space, a certain amount of the BYSA inventory will be used to back vouchers issued as partial payment. The vouchers will circulate in the local territory as an alternative currency (at an exchange rate of 1:1 with the Honduran Lempira) and ultimately be used to buy BYSA products (fuel, cattle concentrate, organic fertilizer, etc.). In Yoro, meanwhile, there are plans to inject 75,000 vouchers. This new currency is supported by the material goods of BYSA, and more vouchers will be introduced into the system when more investments are made or when production increases. Negotiations have begun with a local cooperative saving bank to support the voucher system. Although this seems to be a very promising economic system for a region like Yoro-where it is very difficult to access external investments and where the local circulation of money is very limited-it is difficult to estimate the extent to which people will understand and accept the complementary currency.

Another important link within Gota Verde is the local vocational and technical training institute, CEVER. ${ }^{12}$ Gota Verde is currently developing two types of Jatropha seed presses. One is a very low-tech machine (easy to build, repair, and transport) that will be used by more isolated communities, and built at CEVER. The other is more sophisticated and requires the support of a specialized workshop in the industrial city of San Pedro Sula for its construction. The intention is to have one press unit housed at CEVER and a system of decentralized units in the department of Yoro. In this context, the NGO MDPL is searching for women's groups in different communities that are starting such units for collecting, drying and pressing Jatropha seed. Additionally, the Gota Verde's own small-scale biodiesel unit was built with the collaboration of CEVER students and is located at a CEVER installation. Local students also play an important role in the adaptation of (non-stationary) motors to the Pure Plant Oil (PPO) of Jatropha, while CEVER tractors have been test run on PPO extracted from local Jatropha seeds.

\footnotetext{
${ }^{12}$ Centro de Educación Vocacional Evangélico y Reformado "Dr. Ned van Steenwijk".
} 
Reflections on the territorial approach of Gota Verde

Briefly, Gota Verde's approach is territorial in that it supports the development of sustainable structures based on primarily (though not exclusively) locally-available human and natural resources for the purposes of strengthening peasant agrarian systems. Three main aspects of this may be noted. Firstly, there is the creation of local social structures aimed at developing sustainable production and utilization systems of Jatropha and its related products. These local structures are formed by the aggregation of peasants, researchers, NGO practitioners, workers of the BYSA, and local business that collectively generate local development. Given that the production of biofuel within Gota Verde is intended to be for local consumption, and that the exchange of Jatropha oil will take place in a complementary currency space with a value only within the territory, it is anticipated that the resulting economic, social and energy gains will remain within the locality. In terms of economic revenues, a focus on the production of biodiesel is generally expected to be specifically profitable because the demand for fuels for transport is increasing. In Honduras, however, the prices of diesel and petrol have been kept low by government subsides with the intention of mitigating the effects of the high oil prices. This has consequences for Gota Verde and the commercialization of biodiesel in Yoro. At current diesel prices (around US\$0.6 per liter) pure plant oil may be a feasible diesel substitute, but biodiesel probably not. ${ }^{13}$ Against this, however, one might suggest that the multistakeholder network is now focusing more on biodiesel than on PPO, since a small-scale biodiesel unit is already running whereas no concrete PPO project is in place yet. Meanwhile, at the level of socio-energetics, it might be more desirable to focus on the local needs of peasants that could be covered with PPO (stationary motors, lighting or cooking facilities)_yet biodiesel remains an interesting product for the locality because it could serve as fuel for (highly used) public transport without having to adapt engines. Moreover, diesel is also an important input for agrarian activities. In May 2008, diesel was in short supply in large parts of Honduras due to a combination of factors, including poor planning on the part of importers, and speculation by distributors. May is a critical month for agriculture because it is then that the rainy season begins. Due to its access to selfproduced biodiesel Gota Verde was able to implement its plowing plan, while many other peasants had to postpone this activity. ${ }^{14}$

\footnotetext{
13 Gota Verde estimates (March, 2008) their production costs to be 33.25 (around US\$1.75) Lempiras per gallon (3.785 1) of PPO, and 56.86 Lempira (around US\$3) for the same quantity of biodiesel. The costs of producing biodiesel are high because expensive substances like methanol are required for trans-esterification.

14 Peter Moers, 2009, "personal communication".
}

Secondly, there is the creation of a complementary production system of Jatropha and food crops. A possible problem with the cultivation of Jatropha would be that it takes territory from other food crops. To avoid the substitution of food crops by fuel crops, Gota Verde does not support peasants wishing to dedicate their land entirely to the cultivation of Jatropha. The strategy of Gota Verde is to promote Jatropha as living fences and in intercropping plantations. Since living fences are very popular in the region, the recommendation to plant Jatropha is well received. Peasants see it as a development that adds a new value to a traditional activity. In fact, $40 \%$ of the total Jatropha planted for the 2008 season was for living fences. Gota Verde recommends the intercropping of Jatropha with maize and beans. In this way, not only is the direct competition with the local production of food crops reduced, but so also is the economic risk in planting Jatropha given that plantations are only expected to deliver a profitable harvest five years after planting. The intercropping system is constantly being re-evaluated and improved, leading to new recommendations for planting density, facilitating maintenance of the crop and reducing competition over sunlight. $^{15}$

Practically, however, there is little to fear from Jatropha in terms of competition for crop space because most arable land in the country goes underutilized (EarthTrends 2003; Cerrato 2008). The main reason for this is the generalized lack of access to credit. For peasants especially, Jatropha has the advantage that once a plantation is established the main inputs are labor and fertilizer (in this case, organic, the press cake supplied by BYSA), which means that peasants who supply their own labor can continue the production cycle with little or no financial investment. Rather than raise problems of competition for space, the dynamics generated by Gota Verde might, in fact, stimulate the cultivation of fields that currently lie fallow.

Thirdly, because Honduras is situated within the centre of origin of Jatropha, the local multi-stakeholder network ought to develop and conserve the genetic variety and productive diversity of Jatropha. In this context, the possible risk of the program currently developed would be that regional biodiversity could decrease. The fear is that the widespread cultivation of a very limited number of Jatropha lines might jeopardize the local traditional genetic diversity, which is an important potential source for future plant breeding programs. Farmers might, for example,

\footnotetext{
15 Another important element of these complementary production systems is their effect in controlling erosion, an acute problem in Honduras. The use of the tree-like Jatropha for living-fences along with intercropping on slopes might help to reduce soil erosion, particularly with over $80 \%$ of the country being mountainous (Jansen 1998; Southworth and Tucker 2001).
} 
replace the range of Jatropha varieties growing in their fences with the Cabo Verde which is promoted as a high yielding variety. Moreover, the currently popular imported varieties of Jatropha might in fact turn out to be relatively ill-adapted to local conditions. Gota Verde is testing these lines in different environmental conditions in Yoro, to see which do best in each location. In fact, because countries outside the center of origin are demanding a diversity of Jatropha lines to counterbalance their poor genetic biodiversity (e.g., Basha and Sujatha 2007) and since Yoro (and Honduras in general) possesses a variety of ecological environments, it would seem to be responsible practice, as well as expedient, to research the wealth of local diversity before making any decisions about which lines should be promoted in which parts of the territory. Gota Verde is starting to appreciate this point, and plans to investigate some local lines.

\section{The technological domain: the biotechnologization of Jatropha}

Notwithstanding its variety of traditional uses, Jatropha has primarily come to public attention because the high oil content of it seeds. The PPO extracted by pressing the seeds is of high quality and can be used directly to power stationary motors with a constant rpm (electricity generators, water pumps, etc.), lamps or kitchens or in adapted diesel motors (with a changing rpm). Jatropha oil is also processed (through transesterification) into biodiesel. Jatropha offers peasants a potential source of extra income-especially because this plant can survive on marginal land in relatively dry, poor soils.

These features have led to a good deal of publicity, hype even, around Jatropha. Large concerns and public institutions are investing heavily in Jatropha. ${ }^{16}$ The rationale given for these investments makes it manifest, however, that while most of the Jatropha production systems are located in developing countries, the biodiesel produced will be utilized in wealthier territories-a situation that functionalizes the territories where Jatropha is produced intrinsically relegating local needs, especially those of the poor, the peasant farmers communities, to the level of secondary considerations, at best.

The massive investments in Jatropha are linked to scientific research (Jatropha scientification). Genetics and genomics play an important role in this scientification

\footnotetext{
16 D1-BP Fuel Crops Limited (with 192,000 ha) and Mission Biofuels Australia (with 40,468 ha) are two major private players. There are also large public investments, for example China, for example, claims to have two million ha already under cultivation, and has announced plans to plant an additional 11 million ha by 2010 (Fairless 2007). India has already cultivated 500,000 ha (ibid.).
}

process (Jatropha biotechnologization). For instance, D1-BP Fuel Crops Ltd. (UK), the largest multinational investing in Jatropha, has signed an agreement with KeyGene N.V. (NL), a global leader in the science of genetic fingerprinting, to pursue genomics research in Jatropha. KeyGene genetic fingerprinting technology enables the identification of different Jatropha cultivars through genetic markers, and is expected to significantly increase the efficiency of the D1 breeding program for the development of high-yielding Jatropha cultivars. After having scientificized and biotechnologized Jatropha through genomics, D1 aims to increase oil yields from 1.7 tons per ha to up to 2.7 tons (Manis 2007).

The biotechnologization process is thus strengthening the conversion of the plant into an industrial input for the production of biofuel. Jatropha is appropriated by external actors and structures are created that produce Jatropha as a commodity to be traded in global markets. New labor and power relations emerge as a result. For instance, a situation is introduced whereby small-scale Jatropha farmers find themselves in competition with large fuel multinationals, insofar as they both produce fuel for transportation. The potential that Jatropha might have as source for a locallyoriented production and consumption becomes constricted.

Nevertheless, alternative production systems like Gota Verde with a more locally-oriented (territorial) approach are also shaping the Jatropha future, both through their engagement in a trajectory of scientification and biotechnologization of the plant at the local level, and through their horizontal connectedness with international research institutes.

\section{An alternative biotechnologization approach}

The Plant Research International (PRI) ${ }^{17}$ Jatropha project is financed by a Dutch charitable foundation. PRI Jatropha research falls into three main areas: agronomic performance, global genetic diversity, and process/product optimization. ${ }^{18}$ Research findings are made public and information widely disseminated. The focus here is on the first two areas of investigation, agronomic and genomics research. These studies are coordinated by PRI within the program "Jatropha curcas evaluation, breeding and propagation," which is expected to work as a basis for future plant breeding programs to be coordinated or monitored by local networks, such as Gota Verde.

\footnotetext{
${ }^{17}$ PRI is a business and research center working within the WUR Plant Sciences Group and Applied Plant Research and serving NGOs and industry.

18 This last area of research is conducted by a different department at WUR and focuses on maximizing the efficiency of the seed pressing process, and studying the potential of Jatropha products beyond fuel applications (soap, press cake, paints, etc.).
} 
The agronomic study of Jatropha is based on a literature review, contacts with experts, and field trials in projects in the tropics-e.g. in Mali ${ }^{19}$ and Mozambique, ${ }^{20}$ as well as in Honduras with Gota Verde. Further field trials are planned for the future in which the performance of representative Jatropha individuals from different genetic groups clustered in the genomic study will be checked at suitable research institutes in different climatic regions. The central finding of PRI agronomic research to date (e.g., Jongschaap et al. 2007, Ouwens et al. 2007) is to confirm the great potential for production emphasized by other researchers (Francis et al. 2005; Asselbergs et al. 2006; Achten et al. 2007) that Jatropha has in its natural environment of arid and semiarid lands. Successful traditional applications additional to those already mentioned include employment of the plant for soil water conservation and soil regeneration, and for the production of insecticides, bio-fertilizer and firewood. At the same time, questions are raised about the feasibility of large-scale industrial production of Jatropha for biofuels, which, taken together, undermine confidence in its likely success. Firstly, yield cannot yet be predicted with any degree of accuracy, and promising seed sources that perform successfully in one location may under-perform in another (Ouwens et al. 2007). Secondly, not much is known about the environmental conditions for flowering and fruit setting, which might have significant consequences for mechanical harvesting. Also, Jatropha seems to be resistant to plagues and diseases in its traditional environment (as living fences or as isolated trees), but this resistance is expected to disappear when the crop is cultivated in plantations. Finally, the production of Jatropha might not be a low labor input as has been claimed, so the cost-effective relation for large-scale monoculture plantations might be unprofitable (Achten et al. 2007; Jongschaap et al. 2007).

The PRI genomic research process can be divided into three main stages: collection, genotyping, and the development of molecular markers related to specific traits. ${ }^{21}$ Activities begin with PRI collecting samples of Jatropha worldwide. Leaves and seeds are sent to The Netherlands by companies, NGOs, and research institutes, along with information about the accessions (on productivity, oil

\footnotetext{
19 www.malifolkecenter.org.

20 www.arrakis.nl/jatropha.html.

${ }^{21} \mathrm{PRI}$ is also conducting studies into comparative genomics in which the molecular technologies referred to are used to analyze the similarities between the Jatropha genome and other members of the Euphorbiaceae family to which Jatropha belongs, and on which PRI has genome information (e.g., rubber, castor bean, cassava). The identification of similarities at the genome level will reduce the research effort for Jatropha insofar as it facilitates the annotation of genomic regions and their functions, along with possible future breeding activities through the use of markers already developed for the Jatropha relatives.
}

contents, growth conditions, etc.). Although two countries are over-represented, the project seems to have access to significant biodiversity worldwide.

After collection, the accessions are characterized with molecular markers (genotyping). Genotyping with molecular markers offers the advantage of being able to cluster accessions in genetically similar groups. In this way, a core collection of accessions can be defined that is reduced in size, since (near) identical accessions can be classified as a single entry. This will facilitate future breeding projects. To carry out this activity, PRI's preferred choice had been to use AFLP molecular markers. This technological choice is not a neutral one, however, as AFLP is a patented technology. The patent rights are owned by the company KeyGene which as mentioned above, delivers its technology to D1-under an exclusive contract. The two year agreement provides D1 with exclusive rights to applied contract research and molecular services carried out by KeyGene on Jatropha with AFLP. PRI therefore decided to conduct the genotyping with another unpatented DNA marker technology, NBS profiling (Linde et al. 2004).

In order to achieve an optimal Jatropha production system in a given territory, it is important to know which varieties are used locally. Molecular marker analysis can achieve this identification (when a local variety is identical to a well-described accession), or else assess the similarity of local varieties to known accessions. The classification of local varieties might also help in selecting parent lines for crosses to be made within local breeding programs in order to achieve locally desired traits. For instance, Gota Verde is working with a variety they call India-Salvadorian, since they believe it to have been imported to Honduras from El Salvador, and before that from India. As the India-Salvadorian is the best performing line in Gota Verde peasants' fields, it could be interesting to investigate whether it is indeed a well-adapted Indian variety or actually a local line form Central America. Such knowledge might facilitate future breeding projects.

Following the genotyping, markers are placed near functional genes responsible for the expression of certain desirable traits. In this way, molecular markers can be found which are related to certain traits considered interesting for the cultivation of the plant. For PRI these traits are: oil content per seed, number of seeds per hectare, growth form (e.g., plant height, branching pattern, and leaves size), timing of flowering, disease resistance, toxicity level, and fatty acid composition of the oil. While some traits which are particularly important for Gota Verde-such as the growth pattern or number of seeds in living fences and in intercropping systems with maize or beans-are not considered, the traits cited are, nevertheless, all interesting for the Honduran multi-stakeholder network. If some of the traits being researched are not 
present in local Jatropha varieties, they might be introduced-by crossing varieties, using traditional plant breeding or marker-assisted breeding, or by genetic manipulation-into the local Jatropha diversity in order to enhance the local production systems.

A logic and desirable follow-up to the PRI project within Gota Verde would be the use of the molecular makers in future breeding programs to speed up the breeding process. In many breeding programs, including Jatropha, trait evaluation is a time-consuming process, and it is helpful if the time gap between initial cross and offspring selection for the next cycle of crosses can be reduced. In the case of Jatropha, determining the yield potential using a classical breeding approach is possible after one or two years, but more accurate and relevant data can only be obtained another year or two after that. The identification of a superior genotype after the evaluation is finished will thus take some four years. If information on the yield potential of a Jatropha genotype could be determined in the seedling stage, for example, the process could only take six months at most of the time needed for a seed to grow to flowering (seeding) plant (or until new seeds have been produced). This is possible with a selection based on the presence/absence of molecular markers.

In the following section we will focus on how this biotechnologization process can strengthen local sustainable developments in Yoro.

\section{The domain of re-territorialization: local and global interaction}

Many philosophers of technology (Mackenzie and Wajcman 1985; Bijker et al. 1987; Feenberg 1999) have argued that the human capacity to model what technologies will become is especially significant during the first phase of the technology development, after which technologies normally lose flexibility. The choices made in this early stage of the biotechnologization of Jatropha are therefore crucial if the plant is to be oriented to the strengthening of peasant agrarian systems.

As mentioned, the PRI objective is to strengthen both small-scale and large-scale production systems. This broad objective range leads to tensions in the choices made during the biotechnologization process. For example, the choices made by PRI concerning the traits to be searched through molecular markers are not neutral ones. One of the researched traits is the number of seeds per hectare. More precisely, PRI desires to obtain knowledge about a production system in which Jatropha plants will be arranged in plots of two by three meters, whilst the number of seeds produced in living fence systems or intercropping systems is not considered. It might well be argued, therefore, that the biotechnologization process is introducing into the reterritorialization process a bias for monoculture cultivation, as against the intercropping and living fence production systems typically favored by small-scale Jatropha agriculture.

Likewise, there is an interest in lowering toxicity levels of Jatropha, primarily because reduced toxicity could enable the plant-pressing process waste to be used as cattle feed. Large-scale plantations might favor the creation of spin-off factories for the production of cattle feed, a strategy that has been followed with other energy plants. Such a technological pathway is somewhat in contradiction to some of the interesting social traits of Jatropha, however-for instance, Jatropha is traditionally used as a living fence for cattle and for medical purposes precisely because of its toxicity. Furthermore, since the pressing process is easily performed in small-scale units in the locality, it seems easy to return the press-cake to the fields as fertilizer, which is very important in the low input agriculture of Yoro. This trait search focus thus appears to imply a preference for the usage of waste for cattle feed as opposed to the usage of waste for fertilizer and of the plant for fencing, effectively aiming research at industry rather than farming communities.

Nevertheless, despite these criticisms, there are perspectives for a flexible use of the produced knowledge. The traits searched for are indeed all interesting for Gota Verde, as the network is working with small-scale Jatropha plantations $(2 \mathrm{~m} \times 3 \mathrm{~m}$, and $5 \mathrm{~m} \times 1 \mathrm{~m})$ with or without intercropping, as well as with living fences. Equally, while toxicity reduction might be contrary to the interests of peasant agriculture, other PRI searched traits are not: knowing more about the oil percentage of the seeds, for example, or understanding the timing of flowering can be interesting for all production systems.

Indeed, the choices made in the early stages of sciences and biotechnological research can have significant consequences for the final structural impact that biotechnologies will have in the territories where they are deployed. Several critical thinkers have illustrated the structural features of new biotechnologies and their implications beyond the explicit economic function of increasing productivity. Ruivenkamp (1989, 2005), for instance, addressed the remote control exercised by the agro-industry on certain farmers' activities. Goodman et al. (1987) identified what they termed the industrial appropriation by external institutions of some key farming activities, like crop and pest management, through the supply of industrial inputs. While van der Ploeg (1987) tackled the scientification of agrarian research and the subsequent increasing prescription of farming practices from within the scientific domain. In the biotechnologization process of Jatropha, we can perceive the continued reproduction of these patterns. For instance, through the knowledge about Jatropha-on biodiversity 
and agronomic performance-produced (appropriated?) by PRI through different local networks, we see a research institute located in Western Europe, where Jatropha cannot survive, acquiring an important position within the Jatropha-world (control at a distance?). We can imagine that the standing of PRI in regards Jatropha-related matters will be well respected, the empowerment of the institute translated into new partnerships, biotechnological capacities and prestige in the field.

Notwithstanding these points, however, it should be also emphasized that the empowerment potentiality of the genomic research (biotechnologization) of Jatropha conducted by PRI is oriented not only towards actors and relationships between actors external to the local production systems, but also towards local sustainable development. This emphasis on local sustainable development is highlighted by comparing the Jatropha biotechnologization process conducted by PRI with that being conducted by the company D1. D1 is developing a similar biotechnologization of Jatropha through genomics-i.e., gathering accessions worldwide, developing marker technology, and performing field trials in different places across the globe in order to generate high productive varieties that can stand local biotic and abiotic stresses-but there are fundamental differences between the approaches of D1 and PRI including their attitudes to the spread of information and scope of production, as well as their working ethos.

Regarding information, the sharing of knowledge carries financial implications for profit-making for D1, so it will most probably not make its research on Jatropha public; PRI on the other hand, has a mandate to make public all the knowledge that it produces on this project. Moreover, for PRI knowledge is importantly a tool to be used for the benefit of local sustainable developments, and its strategy is to link its research findings to local projects by reporting findings to small-scale networks of Jatropha production (e.g., Gota Verde). Regarding production, D1 seeks to maximize financial return for investments made, and will most probably produce biofuels, especially biodiesel, for the global market outside of the production territory through their 50/50 partnership with BP. PRI however, also targets the strengthening of the locally-oriented development of the Jatropha system (local production for local consumption). In respect to the working ethos, D1 operates with an abstract, financial model of development (which includes a classical top-down business mode of operation), whereas PRI embraces emerging alternative approaches, characterized, for example, by the loose-knit, multi-faceted networking structures. Finally, D1 policies, one would argue, tend to have the effect of de-territorializationwhereas the semi-public research institute PRI within the working framework generated for the Jatropha project facilitates policy decisions supportive of territorialization.
It is important to remark, however, that while these differences between the D1 and PRI Jatropha biotechnologization processes are clear at the project level, there is some ambivalence at the institutional level. This is due to the privatization process that Dutch universities are currently undergoing. State educational facilities not only conduct research aimed at producing public goods these days, but also sell their services as a source of income. Indeed, the PRI Jatropha project could have been financed by, for instance, D1, rather than a charitable foundation, and oriented towards commercial agriculture rather than small-scale production systems. Fortunately, that has not been the case.

Just as the two biotechnologization trajectories represent, to a certain extent, two rather different worldviews, so also do they face quite different challenges. The possible problems for D1 are not our concern here, but one difficulty that PRI faces might be mentioned. Local Jatropha networks do need a certain level of expertise in order to be able to understand and translate the agronomic, genetic, and genomic knowledge into something useful for the local conditions. The importance of workshops, constant networking and communication cannot be overstated. The provision of systems of sufficient capacity aimed at meeting this in an ongoing, open-ended fashion certainly presents PRI with a managerial challenge. Scientific research maybe useless if practically valuable information is not disseminated at the local level. ${ }^{22}$

Regarding the process of reterritorialization in Honduras, the biotechnologization process conducted by PRI is strengthening and has the potential to further empower local development in Yoro in different ways:

- It has increased awareness among Honduran agrarian researchers that their native Jatropha is a plant with an added value in contemporary societies. However, this appreciation has not yet extended to a full understanding of the genetic wealth of the country's natural Jatropha stock. This is reflected in the present lack of coordinated research investments in Honduras into Jatropha genetic diversity. Nevertheless, some recent initiatives indicate that this may be changing. Gota Verde is starting to investigate Jatropha diversity in Yoro, and a researcher from FHIA has collected thirteen accessions from living fences in Honduras, from which he selected eight samples that were sent to Wageningen for analysis.

- It might help Hondurans not only to learn about the Jatropha genetic wealth of Honduras, but also to show it

\footnotetext{
22 This is a demand that it present even at the level of language: not all local researchers or NGO practitioners know English, so it is also important to translate the English-language scientific publications to other languages spoken in the different localities (at least to Spanish for Honduras).
} 
to and exploit it in the world. ${ }^{23}$ For instance, one study conducted in Guatemala by a Jatropha expert on the oil content of Gota Verde's seeds showed the oil content of their Cabo Verde to be $21.72 \%$, whereas that of a local accession collected from a living fence in a local community is startling high, at $52.29 \% .{ }^{24}$ Since the oil content of the native accession is significantly superior to the Cabo Verde, and since this native line is, of course, well-adapted to local environmental conditions, it is evident that further studies of this line (e.g., at Wageningen) would be useful.

- The molecular characterization in Wageningen of these local samples, and of the other imported cultivars, will be of assistance to Gota Verde in learning both the place of origin of their imported lines, and the genetic relation of imported and local lines to other Jatropha lines. Given the desirability of crossing genetically-separate lines, this is important as input for future breeding programs.

- The molecular analysis may help in finding out whether local lines (native and imported) are valuable materials in respect of specific genetic characteristics (oil content, growth form, etc.). If PRI is able to develop molecular markers for these traits, then the Honduran samples can be tested for them which, in turn, can accelerate the development of lines with the desired qualities for local production.

- The technological knowledge of PRI regarding molecular markers could play an important role in the design of local projects. If the already-established global and local partnerships are strengthened at the local level to facilitate the research of Jatropha in Yoro, the traits that are interesting for the local production systems but which are still not present in the used cultivars could be introduced into these cultivars through breeding projects. It is now up to the different institutes and organizations to search for funds and strengthen the partnerships that can operationalize this trajectory.

The generation of molecular markers related to certain traits is a costly activity (Reece and Haribabu 2007). The knowledge and capacities for this are mainly based in industrially developed regions which have good technological facilities (Fears 2007). For this reason, the centralization of research oriented to marker discovery could be necessary. The fact that the present research is conducted by PRI is beneficial to countries like Honduras and networks like Gota Verde both in so far as it enables costs savings and

\footnotetext{
23 As an example of the genetic wealth of the region expressed in financial terms, we observe the recent sale of the Guatemalan company Octagon for over two million Euros (BioDieselSpain 2007), a major reason for this valuation was the company's germplasm collection of 42 Guatemalan accessions collected in living fences.

24 Daniel Krabatsch, 2008, "personal communication".
}

access to advanced technological capacities. However, such centralization does require that the research institution working on genomics development remains in contact with plant experts all around the world to guarantee that the markers that they discover are indeed relevant for specific localities and available in local accessions that show good combining ability with elite cultivars.

\section{Conclusions}

The socio-agronomic characteristics of Jatropha make it an interesting source of energy and other inputs in rural isolated areas. A scientification and biotechnologization of Jatropha seems to be necessary, however, if sustainable production systems of the plant are to be developed. Against this background, contradictory dynamics in the biotechnologization of Jatropha are in play. On the one hand, Jatropha is being decoupled from its socio-cultural environment to be imbued with the developmental logic of the global market. On the other hand, local multi-stakeholder networks are collaborating with international research institutes to harness Jatropha for local sustainable developments. This article suggests that the biotechnologization of Jatropha (through genomics) might be deployed not only through bioindustrial conglomerates in extending their control over agriculture, but also within the framework of the types of organizations, relationships and interactions here presented, geared towards local sustainable developments. The three domain concept of local sustainable biotechnological developments has been employed to analyze the biotechnogization process here.

In the territorial domain we have seen the struggles of the multi-stakeholder network Gota Verde to harness Jatropha within the small-scale agrarian system of Yoro. Difficult choices remain to be made regarding the local implementation which emphasizes the commercialization of biodiesel or the use of PPO for fuel, as well as researching, maintaining, and developing the local genetic diversity wealth of Jatropha.

In the technological domain, the possibilities of the plant and strategies for genomic development have been considered. A one-dimensional trajectory to develop (at an abstract global level) a single best performing Jatropha line for global purposes (as is the case with the Cabo Verde line) does not appear advisable, since the genetic make up is just one part of the total phenotypic expression of the crop. The production of a technology in isolation (e.g., an elite line of Jatropha) is not in itself bad, but is only appropriate within a specific context. Considering the territorial approach as outlined here, a strategy to develop a multitude of Jatropha lines adapted to a diversity of local production systems might thus be the most appropriate way of linking global and local biotechnological capacities. For 
instance, when a fuel crop is intended to add value to marginal areas, it is obviously important to consider the balance between food and energy crops and other needs (financial, ecological, etc.) in the territory. A complementary system of food and fuel crops might be preferred to the substitution of one by the other (e.g., for commercial purposes). In practice, this should mean introducing into the Jatropha research agenda its performance in living fences and in location-specific intercropping systems (in Yoro, for example, especially with maize and beans).

The domain of re-territorialization has presented the biotechnologization of Jatropha as an ongoing process. Gota Verde is able to take advantage of the research conducted by PRI. Instead of leading to a dependency relationship, such horizontal networks facilitate the use of international genomics facilities in applications at local levels.

Reece and Haribabu (2007, p. 467) argue that, "perhaps, the main constraint to marker discovery is the shortage of people able to do field experiments with phenotypes." Fortunately, however, this is hardly a concern in the case of Jatropha, where a multitude of networks worldwide are experimenting with different phenotypes to understand and sculpt the plant's behavior, including Gota Verde. It seems important, therefore, for all concerned to support these horizontal global-local networks. From the abstract scientific perspective, as well as for commercial interests, localglobal networking provides a vital stock of organized, informed and highly-motivated labor for phenotype experimentation. From the perspective of the local networks, the territorialization is necessary to access contemporary technological capacities and incorporate the research data internationally available. It is also necessary to enable the integration of local needs into and reorientation of international research and development scientific agendas towards the interests of local sustainable developments.

Acknowledgements The author is sincerely thankful for the comments made on previous versions of this article by Prof. Guido Ruivenkamp, Dr. Joost Jongerden, Dr. Henk van den Belt, and Dr Wietse Vroom. The support of Dr. Robert van Loo on the technical issues, and of Andy Hilton with the English was invaluable. I am also greatly indebted to the people who have facilitated my field work-in the Netherlands, at PRI; and in Yoro, Honduras, at Gota Verde, STRO, FUNDER, FHIA, and MPDL, and peasants in the communities of Centro Poblado, Comayagua, Yoro, Sulaco, Lomitas, and Luquigue.

Open Access This article is distributed under the terms of the Creative Commons Attribution Noncommercial License which permits any noncommercial use, distribution, and reproduction in any medium, provided the original author(s) and source are credited.

\section{References}

Achten, W.M., E. Mathijs, L. Verchot, V.P. Singh, R. Aerts, and B. Muys. 2007. Jatropha biodiesel fueling sustainability? Biofuels Bioproducts and Biorefining 1 (4): 283-291.
Adler, J.H. 2000. More sorry than safe: Assessing the precautionary principle and the proposed international biosafety protocol. Texas International Law Journal 35: 173-205.

Asselbergs, B., J. Bokhorst, R. Harms, J.V. Hemert, L.V.D. Noort, C. Velden, R. Vervuurt, L. Wijnen, L.V. Zon, and L. Woltjer. 2006. Size does matter: The possibilities of cultivating Jatropha curcas for biofuels production in Cambodia. Amsterdam: University of Amsterdam.

Basha, S.D., and M. Sujatha. 2007. Inter and intra-population variability of Jatropha curcas (L.) characterized by RAPD and ISSR markers and development of population-specific SCAR markers. Euphytica 156 (3): 375-386.

Bijker, W.E., T.P. Hughes, and T.J. Pinch, eds. 1987. The social construction of technological systems. New directions in the sociology and history of technology. Cambridge, MA: The MIT Press.

BioDieselSpain. 2007. Cie automotive se hace con el $51 \%$ de biocombustibles de Guatemala por 2,3 millones. BioDieselSpain. com.

Bruskiewich, R., G. Davenport, T. Hazekamp, T. Metz, M. Ruiz, M.R. Simon, M. Takeya, M.S. Jennifer Lee, G. Mclaren, and T.V. Hintum. 2006. The generation challenge programme (GCP). Standards for crop data. OMICS 10 (2): 215-219.

Cerrato, L.Y. 2008. Honduras ante la crisis mundial de alimentos: estamos preparados? Financiera 5: 14-16.

Delmer, D.P. 2005. Agriculture in the developing world. Connecting innovations in plant research to downstream applications. PNAS 102 (44): 15739-15746.

Earthtrends. 2003. Agriculture and food-Honduras. Earth Trends. http://earthtrends.wri.org/pdf_library/country_profiles/agr_cou_ 340.pdf. Retrieved 1 Nov 2008.

Fairless, D. 2007. Biofuel. The little shrub that could-maybe. Nature 449 (7163): 652-655.

Fears, R. 2007. Genomics and genetic resources for food and agriculture. Rome, Italy: Food and Agriculture Organization of the United Nations.

Feenberg, A. 1999. Questioning technology. London, New York: Routledge.

Francis, G., R. Edinger, and K. Becker. 2005. A concept for simultaneous wasteland reclamation, fuel production, and socioeconomic development in degraded areas in India: Need, potential and perspectives of Jatropha plantations. Natural Resources Forum 29 (1): 12-24.

Goodman, D., B. Sorj, and J. Wilkinson. 1987. From farming to biotechnology. A theory of agro-industrial development. Oxford, UK: Basil Blackwell Publications.

Gottret, M. V. 2007. Rural innovation and smallholders' livelihoods: Modes of intervention in hillside communities of Latin America. Doctoral diss., The Hague, The Netherlands: Institute of Social Studies.

Hettne, B. 1995. Development theory and the three worlds: Towards an international political economy of development. London: Longman Scientific and Technical.

Humphrey, C. 1997. Honduras handbook, including the Bay Islands and Copan. Emeryville, CA: Moon Publications.

Jansen, H. G. P., P. B. Siegel, F. Alwang, and F. Pichón. 2006. Understanding the drivers of sustainable rural growth and poverty reduction in Honduras. En breve 87.

Jansen, K. 1998. Political ecology, mountain agriculture, and knowledge in Honduras. Doctoral diss., Wageningen, The Netherlands: Wageningen University.

Jongschaap, R.E.E., W.J. Corré, P.S. Bindraban, and W.A. Brandenburg. 2007. Claims and facts on Jatropha curcas L. Global Jatropha curcas evaluation, breeding and propagation programme. Wageningen, The Netherlands: Stichting Het Groene Woudt. 
La Prensa. 2006. Presidente de Honduras prevé que biodiesel asegure $30 \%$ de energía en cinco años. La Prensa April 2.

Linde, C.G.V.D., D.C.A.E. Wouters, V. Mihalka, E.Z. Kochieva, M.J.M. Smulders, and B. Vosman. 2004. Efficient targeting of plant disease resistance loci using NBS profiling. Theoretical and Applied Genetics 109 (2): 384-393.

Louwaars, N.P., E. Thorn, J. Esquinas-Alcazar, S. Wang, A. Demissie, and C. Stannard. 2006. Access to plant genetic resources for genomic research for the poor: From global policies to target-oriented rules. Plant Genetic Resources Newsletter 4 (1): 54-63.

Mackenzie, D., and J. Wajcman, eds. 1985. The social shaping of technology: How the refrigerator got its hum. Milton KeynesPhiladelphia, PA: Open University Press.

Magnaghi, A. 2005. The urban village: A charter for democracy and local self-sustainable development. New York, NY: Zed Books.

MAMUNCRAC. 2007. Propuesta de ordenamiento territorial Yoro. Yoro, Honduras: Mancomunidad de Municipios de la Cuenca del Río Aguan y Cuyamapa.

Manis, E. 2007. Interview interim results 2007. http://www.d1plc. com/aboutDownloads.php. Accessed 12 Oct 2008.

Noble, D. 1978. Social choice in machine design: The case of automatically controlled machine tools, and a challenge for labor. Politics and Society 8 (3-4): 247-312.

Ouwens, K.D., G. Francis, Y.J. Franken, W. Rijssenbeek, A. Riedacker, N. Foidl, R. Jongschaap, and P. Bindraban. 2007. Positon paper on Jatropha curcas. State of the art, small and large scale project development. Wageningen, The Netherlands: FACT.

Puente-Rodríguez, D. 2007. Redesigning the production of the Bacillus thuringiensis bio-pesticide within the context of subsistence agriculture in Andhra Pradesh, India. Asian Biotechnology and Development Review 9 (3): 55-81.

Puente-Rodríguez, D. 2008. The Wiphala genomics: The deployment of molecular markers in small-scale potato crop systems in the Bolivian Andes. The European Journal of Development Research 20 (3): 377-398.

Reece, J.D., and E. Haribabu. 2007. Genes to feed the world: The weakest link? Food Policy 32 (4): 459-479.

Rothkopf, G. 2007. A blue print for green energy in the Americas: Strategic analysis for opportunities of Brazil and the hemi- sphere. In The Global Biofuels Outlook 2007, Inter American Development Bank (IDB). Washintong, DC: IDB.

Ruivenkamp, G. 1989. De invoering van biotechnologie in de agroindustrièle oroductieketen: de overgang naar een nieuwe arbeidsorganisatie. Amsterdam, Holland: Universiteit van Amsterdam.

Ruivenkamp, G. 2005. Wetenschap in de samenleving: de ontwikkeling van biotechnologie en genomics op-maat. Inaugural Speech: Vrij Universiteit Amsterdam. Inaugural speech.

Ruivenkamp, G., S. Hisano, and J. Jongerden. 2008. Introduction. In Reconstructing biotechnologies: Critical social analyses, ed. G. Ruivenkamp, S. Hisano, and J. Jongerden, 15-26. Wageningen, The Netherlands: Wageningen Academic Publishers.

Sclove, R.E. 1995. Democracy and technology. London, UK: The Guilford Press.

Southworth, J., and Tucker. 2001. The influence of accessibility, local institutions, and socioeconomic factors on forest cover change in the mountains of western Honduras. Mountain Research and Development 23 (3): 276-283.

van der Ploeg, J.D. 1987. De verwetenschappelijking van de landbouwbeoefening. Wageningen, The Netherlands: Wageningen University.

Winner, L. 1985. Do artifacts have politics? In The social shaping of technology: How the refrigerator got its hum, ed. D. Mackenzie and J. Wajcman, 26-38. Milton Keynes, Philadelphia, PA: Open University Press.

\section{Author Biography}

Daniel Puente Rodríguez is a $\mathrm{PhD}$ candidate at the Critical Technology Construction (Social Sciences Group) in the Wageningen University and Research Centre (NL), at the Athena Institute (Faculty of Earth and Life Sciences) Vrije University Amsterdam (NL), and at the Centre for Genomics in Society at Exeter University (UK). His research focuses on whether and how the co-creation of social and technical elements in biotechnology and genomics research takes place and whether and how the co-creation can be opened and reconstructed by resource-poor farmers and local development organizations towards local sustainable developments. 